Systemy Logistyczne Wojsk

Zeszyt 54 (2021)

ISSN 1508-5430, s. 167-181

Military Logistics Systems

Volume 54 (2021)

ISSN 1508-5430, pp. 167-181
Instytut Logistyki Wydział Bezpieczeństwa, Logistyki i Zarządzania

Wojskowa Akademia Techniczna

w Warszawie

Institute of Logistics

Faculty of Security, Logistics and Management Military University of Technology

in Warsaw

\title{
A multidimensional comparative analysis of the labor market in the United States in terms of economic security and its impact on providing logistical support for the US Armed Forces stationed in Poland
}

\author{
Wielowymiarowa analiza porównawcza rynku pracy \\ w Stanach Zjednoczonych w czasie oddziaływania pandemii \\ COVID-19 i jego wpływ na zapewnienie wsparcia logistycznego \\ SZ USA stacjonujących w Polsce
}

\author{
Bartosz Kozicki \\ bartosz.kozicki@wat.edu.pl; ORCID:0000-0001-6089-952X \\ Military University of Technology \\ Faculty of Security, Logistics and Management \\ Institute of Logistics \\ Szymon Mitkow \\ szymon.mitkow@wat.edu.pl; ORCID: 0000-0003-2845-2589 \\ Military University of Technology \\ Faculty of Security, Logistics and Management
}

\begin{abstract}
Maintaining economic security requires constant analysis and evaluation of the situation on the labor market in terms of making decisions in the aspect of quick and effective counteracting of encountered problems. One of the forms of market observation is multidimensional comparative analyzes of data that reflect its condition and economic situation. The study uses a multidimensional comparative analysis of the employed and unemployed in respective US states in four groups of dependent variables in the form of months: January 2020, November 2020, December 2020 and January 2021. The research period of the study covers the impact of the crisis caused by the COVID-19 infectious disease pandemic. The research problem of the study focuses on multidimensional comparative analyses of unemployment rates in the United States in terms of the impact of the COVID-19 pandemic. The aim of the study is to conduct a multidimensional comparative analysis of the employed and unemployed in respective US states in the aspect of the impact of the COVID-19 pandemic. For the adopted research problem and the
\end{abstract}


purpose of the work, the following research hypothesis is outlined: To what extent has the COVID-19 pandemic affected the unemployment rates in the United States? The following research methods were used in the article: analysis of the literature on issues related to unemployment rates in the United States, multidimensional analyzes and economic security. Overcoming obstacles and returning to pre-crisis situations now requires preparing society for pre-pandemic levels by ensuring people's health safety by vaccinated the majority of the population.

Keywords: unemployment, US unemployment rates, multivariate analyzes, economic security

Abstrakt. Utrzymanie bezpieczeństwa ekonomicznego wymaga stałej analizy i oceny sytuacji na rynku pracy pod względem podejmowania decyzji w aspekcie szybkiego i skutecznego przeciwdziałania napotkanym problemom. Jedną z form obserwacji rynku są wielowymiarowe analizy porównawcze danych, które odzwierciedlają jego kondycję i sytuację gospodarczą. W badaniu wykorzystano wielowymiarową analizę porównawczą zatrudnionych i bezrobotnych w poszczególnych stanach USA w czterech grupach zmiennych zależnych w postaci miesięcy: stycznia 2020 r., listopada 2020 r., grudnia 2020 r. oraz stycznia 2021 r. Okres badawczy obejmuje wpływ kryzysu spowodowanego pandemią chorób zakaźnych COVID19. Problem badawczy koncentruje się na wielowymiarowych analizach porównawczych stopy bezrobocia w Stanach Zjednoczonych pod względem wpływu pandemii COVID-19. Głównym celem badania jest przeprowadzenie wielowymiarowej analizy porównawczej zatrudnionych i bezrobotnych w odpowiednich stanach USA w aspekcie wpływu pandemii COVID-19. W przypadku przyjętego problemu badawczego i celu prac przedstawiono następującą hipotezę badawczą: W jakim stopniu pandemia COVID-19 wpłynęła na stopę bezrobocia w Stanach Zjednoczonych? W artykule wykorzystano następujące metody badawcze: analiza literatury na tematy związane ze stopą bezrobocia w Stanach Zjednoczonych, wielowymiarowe analizy i bezpieczeństwo ekonomiczne. Przezwyciężenie przeszkód i powrót do sytuacji sprzed kryzysu wymaga obecnie przygotowania społeczeństwa do funkcjonowania na poziomie sprzed pandemii poprzez zapewnienie bezpieczeństwa zdrowotnego ludzi poprzez szczepienie większości populacji.

Słowa kluczowe: bezrobocie, stopa bezrobocia w USA, analizy wielowymiarowe, bezpieczeństwo gospodarcze

\section{Introduction}

The premise of the comparative analysis of the labor market in the United States was of an increase in unemployment rates in April 2020 to 14.7\%, it was higher than ever in at least the past 70 years (https://eu.usatoday.com/story/money / 2020/08/08 / cities-with-the-worst-unemployment-since-the-pandemic-started / 42187029/, as of March 27, 2021). From February to March 2020, the unemployment rate increased by 11.2 percentage points, which means that around 20.5 million people lost their jobs during this period (https://businessinsider.com.pl/twoje-pieniadze/praca/ bezrobocie-w -April-2020-rw-usa-caused by-coronavirus / gk157xg, as of November 27, 2020). Service industries, in particular accommodation and catering services, were severely affected, although health and welfare services, arts, entertainment and recreation, transport, storage and manufacturing industries were also mentioned (https://www.theguardian.com/business/2020/ Mar / 26 / us-unemployment-rate-coronavirus-business, as of March 27, 2021). Unemployment rates have been slowly declining in the United States since April 2020, but the pre-COVID-19 state has not yet been reached. 
In the study a research problem was formulated. The research problem of the study focuses on multidimensional comparative analyses of unemployment rates in the United States in terms of the impact of the COVID-19 pandemic.

The aim of the study is to conduct a multidimensional comparative analysis of the employed and unemployed in respective US states in the aspect of the impact of the COVID-19 pandemic.

For the adopted research problem and the purpose of the work, the following research hypothesis is outlined:

To what extent has the COVID-19 pandemic affected the unemployment rates in the United States?

The following research methods were used in the article: analysis of the literature on issues related to unemployment rates in the United States, multidimensional analyzes and economic security.

The study consists of an introduction, three substantive points, a summary and conclusions.

\section{Analysis of the literature on the research subject}

An analysis of the literature shows that the United States, with a population of 332 million people, is one of the strongest economies in the world (https://www. worldometers.info/world-population/us-population/, as of 11/27/2020). The economy of the United States is considered stable although there have been crises in its history. The highest unemployment rate in the history of the United States was recorded during the Great Depression between 1929-1933 - on May 1, 1933 it reached the level of 25.59\% (https://historia.org.pl/2020/04/03/wielki-kryzys- economic-1929-1933-the biggest-crisis-in-history-capitalism /, state on October 28, 2020). The dynamics of the increase in the unemployment rate to such a high level was gradual and lasted for several years. On the other hand, the infectious disease COVID-19 led to a situation where the spike in the unemployment rate took place in two months with a magnitude unprecedented in US history, i.e. 11.2 (Mitkow, Kozicki, 2021, https://www.pewresearch.org/fact-tank/2020/06/11/unemployment-rose-higherin-three-months-of-covid-19-than-it-did-in-two-years- of-the-great-recession /, as of 03/27/2021). On March 18, 2020 the former President Donald Trump signed the Families First Coronavirus Response Act (FFCRA) which provided flexibility for state unemployment agencies and additional administrative funding in response to the COVID-19 pandemic. The enacted law expanded the ability of states to provide unemployment insurance to many workers affected by the COVID-19 pandemic including those who normally do not qualify for unemployment benefits (https:// www.dol.gov/coronavirus/unemployment-insurance, state on March 27, 2021). 
In April 2020, the highest unemployment rate in the US was recorded in the following states: Nevada - 28.3\%; Michigan - 22.7\% and Hawaii 22.3\% (B. Kozicki, M. Kalwasiński, 2021). In other states, it oscillated around the level of $12.76 \%$. The lowest unemployment rate in April 2020 in the US was recorded in Connecticut - 8.1\%.

The analysis of the literature shows that the unemployment rate is the quotient of the product of the unemployed and $100 \%$ by the sum of the employed and unemployed (https://www.naukowiec.org/wzory/ekonomia/stopa-bezrobocia_906. $\mathrm{html}$, as of 03/26/2021). The unemployed are people who are not employed, they are looking for a job and accepting the current salary (D. Begg, G. Vernasca, S. Fischer, R. Dornbusch, 2014, p. 307). The study attempts to analyze one of the largest labor markets, which is the United States, in terms of the impact of the infectious disease COVID-19.

The first case of COVID-19 was recorded in December 2019 in Wuhan, China (N. Zhu, D. Zhang, et al., January 24, 2020). The first case of this infectious disease in the United States was observed on January 19, 2020 in Snohomish County, Washington (https://www.nejm.org/doi/full/10.1056/NEJMoa2001191, as of 03/27/2021]) The World Health Organization on March 11, 2020 declared COVID-19 a pandemic (Satomi et al., April 2020) Since then, mandatory restrictions have been introduced in respective countries of the world and remedies have been sought: transport was limited, especially in the aviation sector, the use of disinfectants and temperature measurements was ordered, temporary hospitals were established (Matuka, September 2020). By the end of 2020, the United States had surpassed 20 million SARS-CoV-2 infections and more than 346,000 deaths. Worldwide, the number of cases increased to 83,832,334 and 1,824,590 deaths (https://www.ajmc.com/view/atimeline-of-covid19-developments-in-2020; as of 03/27/2021).

The closing of borders and the slowdown in air transport has led to the decreasing demand for crude oil and its global price falls (Kingsly, H. Kouam, January 2020) to levels hovering around $\$ 9$ a barrel. This, in turn, was the main premise for the rise in unemployment rates in the United States.

The slowdown in the air transport sector, falling oil prices, rising unemployment rates and other factors have undermined the economic security of the United States.

According to Nurzyńska, economic security is the certainty of the survival and development of the economic system of a country and the maintenance of its international position (Nurzyńska, 2016, p. 22). Maintaining economic security requires constant analysis and evaluation of the situation on the labor market in terms of making decisions in the aspect of quick and effective counteracting of encountered problems. One of the forms of market observation is multidimensional comparative analyzes of data that reflect its condition and economic situation. The data undoubtedly include the number of the employed and unemployed in dynamic terms. The analysis of the literature shows that a multidimensional comparative analysis consists in ordering a relatively homogeneous set of objects in order to make 
decisions (Łuniewska, Tarczyński, 2006, p. 10). The research involved grouping and specifying of data for further analysis and evaluation.

The research began with a multivariate comparative analysis of the number of the employed and unemployed in the United States.

\section{Multidimensional comparative analysis of the number of the employed and unemployed in the United States}

The research began with an analysis of the number of people employed in the United States. To achieve this goal, data on employment in respective states and regions of the USA in four months have been outlined in Figure 1: January 2020, November 2020, December 2020 and January 2021.

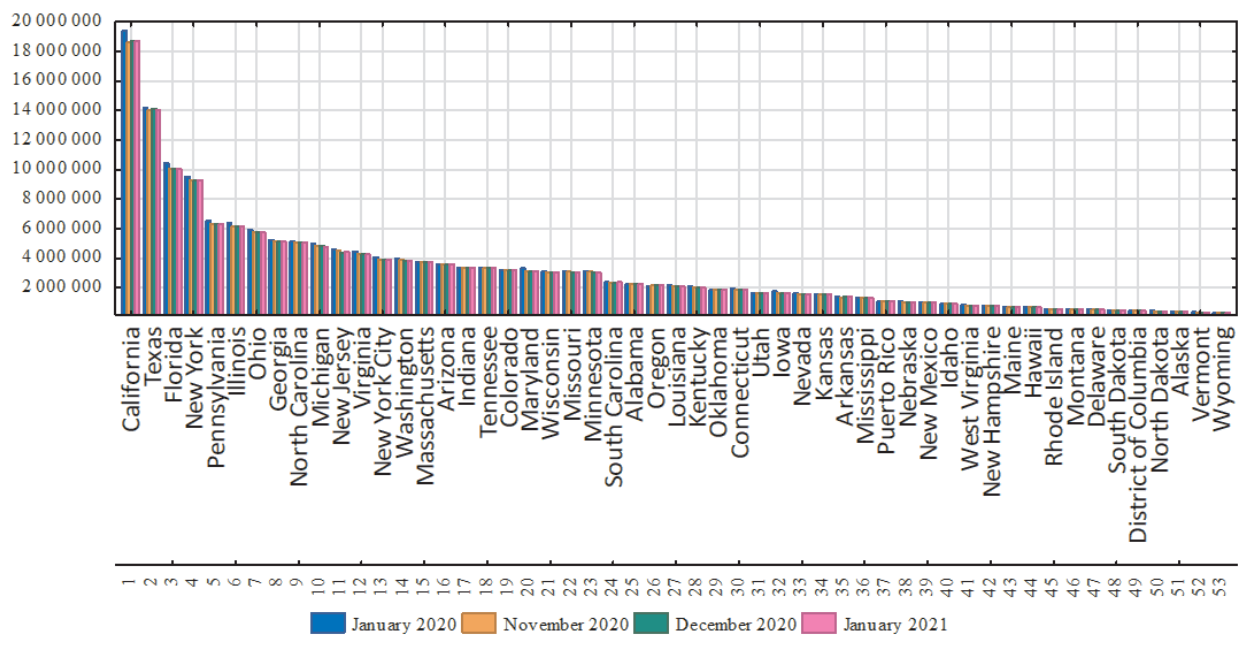

Fig. 1. Bar chart of employment in respective US states (including regions) in four months: January 2020, November 2020, December 2020 and January 2021

Source: Own study based on data obtained from the website: https://www.bls.gov/news.release/laus. t01.htm, as of March 24, 2021

The observation of Figure 1 allows for the conclusion that the number of employees in the United States varies. Employment of 6 million people was observed in six US states. Leaders like California employ around 18 million. In 30 respective states in the United States, the number of employees is less than 3 million. For illustrative purposes, the number of employees in individual US states was ranked in the months: January 2020, November 2020, December 2020, January 2021 - by calculating their median. The ranking results are as follows: 1 . California $(18,687,224), 2$. Texas $(14,098,306), 3$. Florida $(10,056,390), 4$. New York $(9,287,303)$, 
5. Pennsylvania $(6,310,522)$, 6. Illinois $(6,155,950)$, 7. Ohio $(5,766,458), 8$. Georgia $(5,114,420), 9$. Northern California $(5,039,346), 10$. Michigan $(4,855,507), 11$. New Jersey $(4,453,885), 12$. Virginia $(4,263,186), 13$. New York City $(3,868,598), 14$. Washington $(3,839,090), 15$. Massachusetts $(3,754,884)$, 16. Arizona ( 3569 985), 17. Indiana (3 345 831), 18. Tennessee (3 315 911), 19. Colorado (3 171 536), 20. Maryland (3 112 855), 21. Missouri (3,056 368), 22. Wisconsin (3,055,305), 23. Minnesota $(3,053,066), 24$. South Carolina $(2,358,024), 25$. Alabama $(2,260,098)$, 26. Oregon $(2,137,113), 27$. Louisiana (2,094,834), 28. Kentucky (1,986,558), 29. Oklahoma $(1,861,880), 30$. Connecticut $(1,843,248), 31$. Utah $(1,630,879), 32$. Iowa $(1,625,083), 33$. Nevada $(1,523,299), 34$. Kansas $(1,507,968), 35$. Arkansas $(1,374,122)$, 36. Mississippi $(1,278,313))$, 37. Puerto Rico $(1,054,741)$, 38. Nebraska $(1,024,778)$, 39. New Mexico (960,211), 40. Idaho (900,224), 41. West Virginia (796,479), 42. New Mexico Hampshire (763 169), 43. Maine (669 166), 44. Hawaii (655 750), 45. Rhode Island (539 545), 46. Montana (533 742), 47. Delaware (484 657), 48. Dakota South $(467,260), 49$. District of Columbia $(409,470), 50$. North Dakota $(404,516)$, 51. Alaska (354,053), 52. Vermont (316,566), and 53. Wyoming $(295,076)$.

The data compiled in Figure 1 shows that between the data on the dependent variables January 2020 and January 2021 there are differences in the form of a decline in the number of employees in the USA in respective states and regions caused by the infectious disease COVID-19. For research purposes, the differences between the same months - January - between 2020 and 2021 are outlined. The results of the research are summarized in Figure 2.

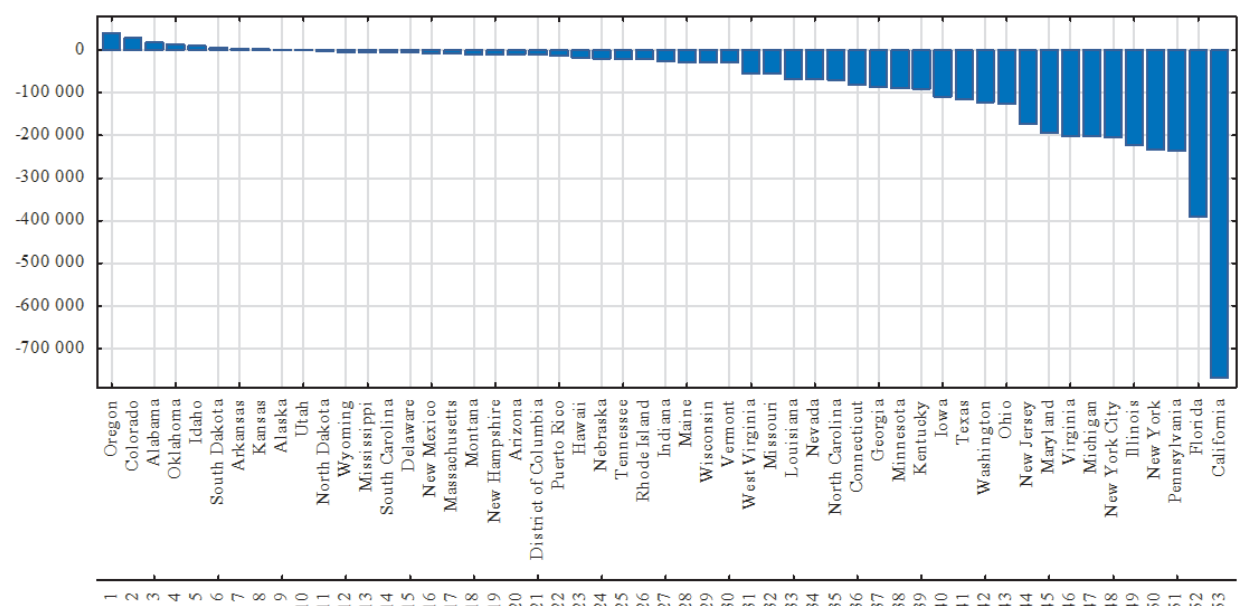

Fig. 2. Bar chart of the difference in employment in respective US states (including regions) between January 2020 and January 2021

Source: Own study based on data obtained from the website: https://www.bls.gov/news.release/laus. t01.htm, as of March 24, 2021 
Figure 2 shows that the difference between the data on the number of employees between January 2020 and January 2021 in the US was positive in 10 states and negative in the remaining 43 . The ranking of the difference from highest to lowest is as follows: 1. Oregon (40,524), 2. Colorado $(28,670)$, 3. Alabama (17,796), 4. Oklahoma $(14,067), 5$. Idaho $(10,264), 6$. South Dakota $(6,526), 7$. Arkansas $(3,662), 8$. Kansas $(2,256), 9$. Alaska $(1,608), 10$. Utah (122), 11. North Dakota $(-3,147), 12$. Wyoming $(-3,511), 13$. Mississippi $(-4,186), 14$. South Carolina $(-5,336), 15$. Delaware $(-5,886)$, 16. New Mexico (-6,244), 17. Massachusetts $(-7,093), 18$. Montana $(-9,734), 19$. New Hampshire (-10,618), 20. Arizona (-10,642), 21. District of Columbia (-11,196), 22. Puerto Rico (-13,567), 23. Hawaii (-17,978), 24. Nebraska (-19,505), 25. Tennessee $(-21,503), 26$. Rhode Island $(-21,733), 27$. Indiana $(-25,264), 28$. Maine $(-28,228)$, 29. Wisconsin $(-28,502), 30$. Vermont $(-28,998), 31$. West Virginia $(-53,956), 32$. Missouri $(-54,736), 33$. Louisiana $(-66,933), 34$. Nevada $(-67,720), 35$. North Carolina $(-69,408), 36$. Connecticut $(-81,267), 37$. Georgia $(-85,963), 38$. Minnesota $(-89,948)$, 39. Kentucky (-91 345), 40. Iowa (-109,051), 41. Texas $(-115,671)$, 42. Washington $(-121,776), 43$. Ohio $(-125,519), 44$. New Jersey $(-173,429)$, 45. Maryland $(-193,320)$, 46. Virginia (-200,228), 47. Michigan $(-200,430), 48$. New York City $(-204,516), 49$. Illinois $(-223,419), 50$. New York $(-233,924), 51$. Pennsylvania $(-236,741), 52$. Florida $(-390,149)$ and 53 . California $(-768,143)$. In total, the decline in the number of employees in the United States between January 2020 and 2021 was by 4,114,971.

The next stage of the research is the analysis of the dynamics of changes in the number of employees in the market in respective US states in four months: January 2020, November 2020, December 2020 and January 2021. The results are shown in Figure 3.

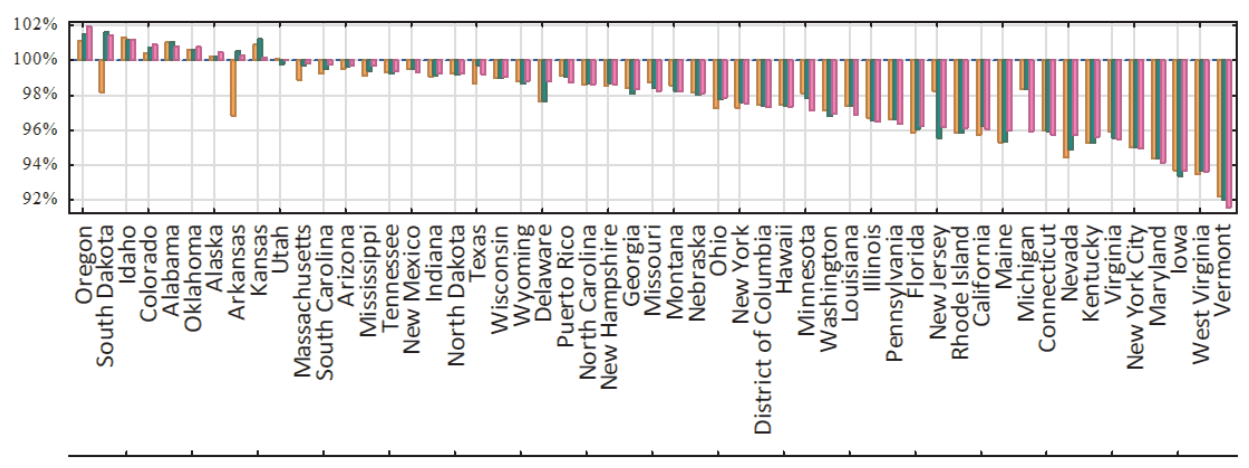

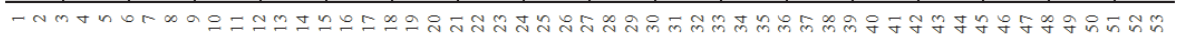
January $2020 \square$ November $2020 \square$ December $2020 \square$ January 2021

Fig. 3. Bar chart of dynamics indices based on a fixed number of employees in respective US states (including regions) in four months: January - 2020, November 2020, December 2020 and January 2021 (constant - the number of available labor in respective states and US regions) in January 2020) Source: Own study based on data obtained from the website: https://www.bls.gov/news.release/laus. t01.htm, as of March 24, 2021 
The dynamics indices in Figure 3 based on a fixed number of employees in respective US states show that in the time period from January 2020 to January 2021 in 10 US states there was an upward trend. On the other hand, in the remaining 43 states and regions of the USA, a typical decline. The ranking of highest to lowest fixed-based dynamics in January 2021 in the USA in respective states is as follows: 1. Oregon (101.92\%), 2. South Dakota (101.41\%), 3. Idaho (101.15\%), 4. Colorado (100.91\%), 5. Alabama (100.79\%), 6. Oklahoma (100.76\%), 7. Alaska (100.46\%), 8. Arkansas (100.27\%), 9. Kansas (100.15\%), 10. Utah (100.01\%), 11. Massachusetts (99.81\%), 12. South Carolina (99.77\%), 13. Arizona (99.70\%), 14. Mississippi (99.67\%), 15. Tennessee (99.36\% ), 16. New Mexico (99.35\%), 17. Indiana (99.25\%), 18. North Dakota (99.23\%), 19. Texas (99.18\%), 20. Wisconsin (99.08\%), 21. Wyoming (98.82\%), 22. Delaware (98.81\%), 23. Puerto Rico (98.73\%), 24. North Carolina (98.64\%), 25. New Hampshire (98.63\%), 26. Georgia (98.35\%), 27. Missouri (98.23\%), 28. Montana (98.21\%), 29. Nebraska (98.13\%), 30. Ohio (97.87\%), 31. New York (97.54\%), 32. District of Columbia (97.34\%), 33. Hawaii (97.33\%), 34. Minnesota (97.11\%), 35. Washington (96.92\%), 36. Louisiana (96.89\%), 37. Illinois (96.49\%), 38. Pennsylvania (96.38\%), 39. Florida (96.27\%), 40. New Jersey (96.21\%), 41. Rhode Island (96.13\%), 42. California (960.5\%), 43. Maine (95.97\%), 44. Michigan (95.97\%), 45. Connecticut (95.77\%), 46. Nevada (95.76\%), 47. Kentucky (95.61\%), 48. Virginia (95.50\%), 49. New York City (94.98\%), 50. Maryland (94.14\%), 51. Iowa (93.17\%), 52. West Virginia (93.65\%) and 53. Vermont (91.56\%).

The further stage of the research is the analysis of the number of the unemployed in respective US states in four months: January - 2020, November 2020, December 2020 and January 2021. The results of the research are outlined in Figure 4.

Figure 4 shows that during the COVID-19 pandemic, unemployment levels rose in all US states. For research purposes, in Figure 4, the ranking of unemployment in the USA in respective states was shown, taking as the basis the results of the medians for the period: January - 2020, November 2020, December 2020 and January 2021. The results of ranking from the highest to the lowest value of unemployment are as follows: 1. California (1 650 425), 2. Texas (964 877), 3. New York (804 877), 4. Florida (498 423), 5. Illinois (498 423), 6. New York City (462 252), 7. Pennsylvania $(446,737), 8$. New Jersey $(342,667), 9$. Michigan $(333,737), 10$. Ohio $(313,226), 11$. Massachusetts (304,041), 12. North Carolina (303,241), 13. Georgia (264 841), 14. Arizona (240 563), 15. Washington (234 032), 16. Virginia (231 744), 17. Colorado (214 768), 18. Maryland (204 375), 19. Tennessee (177,338), 20. Louisiana $(161,620)$, 21. Connecticut (150,496), 22. Indiana (147,538), 23. Minnesota (140,097), 24. Oregon (133,579), 25. Missouri (132,967), 26. South Carolina (128,519), 27. Nevada $(124,647), 28$. Wisconsin $(119,258), 29$. Kentucky $(108,562)$, 30. Alabama $(101,642)$, 31. Puerto Rico (96,774), 32. Mississippi $(83,013), 33$. Oklahoma $(82,400), 34$. New Mexico (82,263), 35. Hawaii (67,199), 36. Arkansas $(65,354)$, 37. Kansas $(61,450)$ 38. Iowa $(58,623), 39$. West Virginia $(52,616), 40$. Utah $(51,705), 41$. Rhode Island 
(40,88 43), 42. District of Columbia (35,175), 43. Nebraska (33,573), 44. Maine (33,055), 45. Idaho (32,820), 46. New Hapshire (28,186), 47. Delaware (28 049), 48. Alaska (23,075), 49. Montana (21,809), 50. North Dakota (18,615), 51. Wyoming $(15,182), 52$. South Dakota $(14,983)$, and 53. Vermont (10 519).

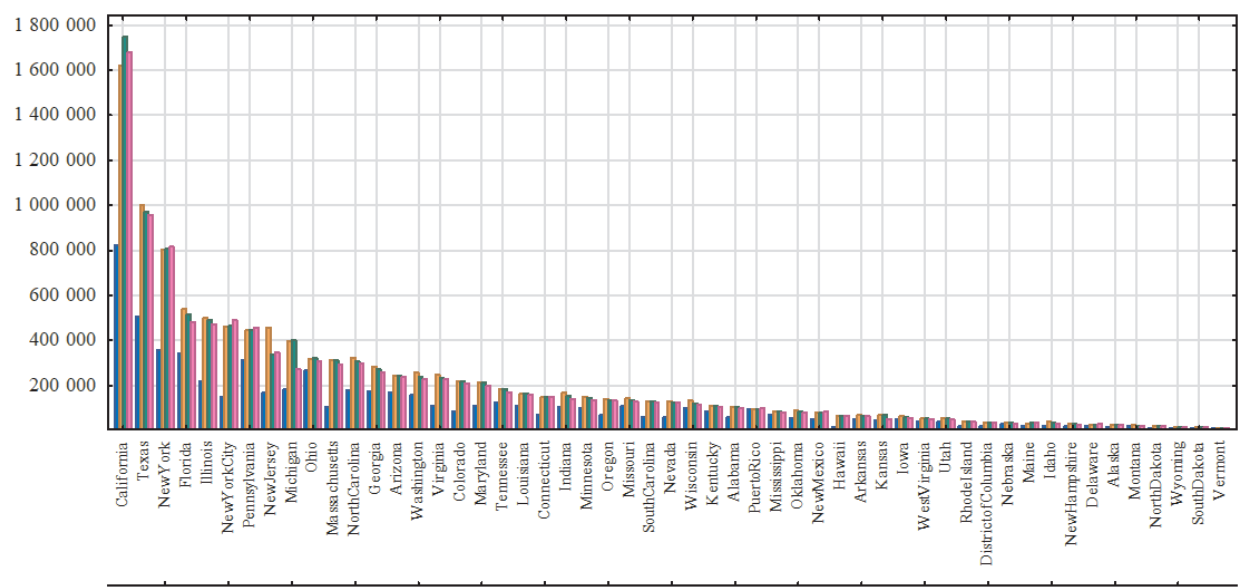

$\square$ January $2020 \square$ November2020 $\square$ December2020 $\square$ January 2021

Fig. 4. Bar chart of the number of the unemployed in respective US states and regions in four months: January - 2020, November 2020, December 2020 and January 2021

Source: Own study based on data obtained from the website: https://www.bls.gov/news.release/laus. t01.htm, as of March 24, 2021

The next stage of the research will be to outline the difference in the number of unemployed people between the same months of January in 2020-2021. The results are presented in Figure 5.

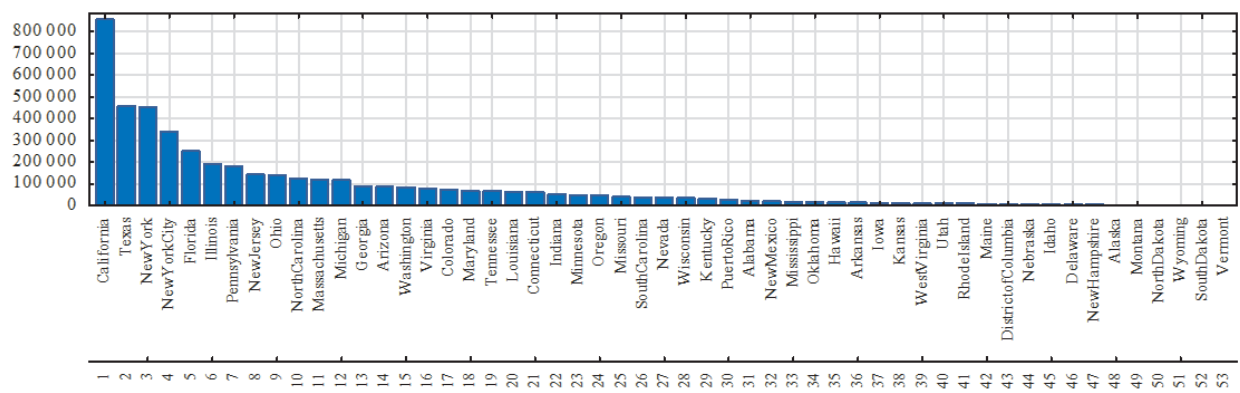

Fig. 5. Bar chart of the difference in the number of the unemployed in particular states and regions of the USA between January 2020 and January 2021

Source: Own study based on data obtained from the website: https://www.bls.gov/news.release/laus. t01.htm, as of March 24, 2021 
The ranking of the difference in the number of the unemployed in respective US states between January 2020 and January 2021 (Fig. 5) is as follows: 1. California $(856,303), 2$. Texas $(456,781), 3$. New York $(453,690), 4$. New York City $(340,806)$, 5. Florida $(251,960), 6$. Illinois $(188,123), 7$. Pennsylvania $(180,199), 8$. New Jersey $(143,009), 9$. Ohio (139,705), 10. North California (126,576), 11. Massachusetts $(117,994), 12$. Michigan (117,295), 13. Georgia $(87,266), 14$. Arizona $(86,229), 15$. Washington $(84,747), 16$. Virginia $(78,946), 17$. Colorado (71,553), 18. Maryland $(67,702), 19$. Tennessee $(66,036), 20$. Louisiana $(63,545), 21$. Connecticut $(60,663)$, 22. Indiana (53,198), 23. Minnesota $(49,278), 24$. Oregon $(46,044), 25$. Missouri $(39,307), 26$. South Carolina $(38,321), 27$. Nevada $(37,428), 28$. Wisconsin $(34,730)$, 29. Kentucky $(33,697), 30$. Puerto Rico $(23,967), 31$. Alabama $(20,669), 32$. New Mexico (20,281), 33. Mississippi (17,834), 34. Oklahoma (14 742), 35. Hawaii (14 281), 36. Arkansas (13,832), 37. Iowa (13,404), 38. Kansas (11,229), 39. West Virginia $(10,161), 40$. Utah $(9,961), 41$. Rhode Island $(9,122), 42$. Maine $(8,448), 43$. District of Columbia $(8,216), 44$. Nebraska $(8,054)$, 45. Idaho $(7,248), 46$. Delaware $(5,926)$, 47. New Hampshire (4,773), 48. Alaska (1,862), Montana (1,800), 50. North Dakota $(1,785), 51$. Wyoming $(1,649), 52$. South Dakota $(1,330)$ and 53 . Vermont $(1,002)$. The arithmetic mean of the analyzed data is $86,433.53$ while the median is 37,428 . The standard deviation from the arithmetic mean was 148,507.7 unemployed.

Then, the dynamics of changes in unemployment in respective US states in four months was analyzed: January - 2020, November 2020, December 2020 and January 2021 (Fig. 6).

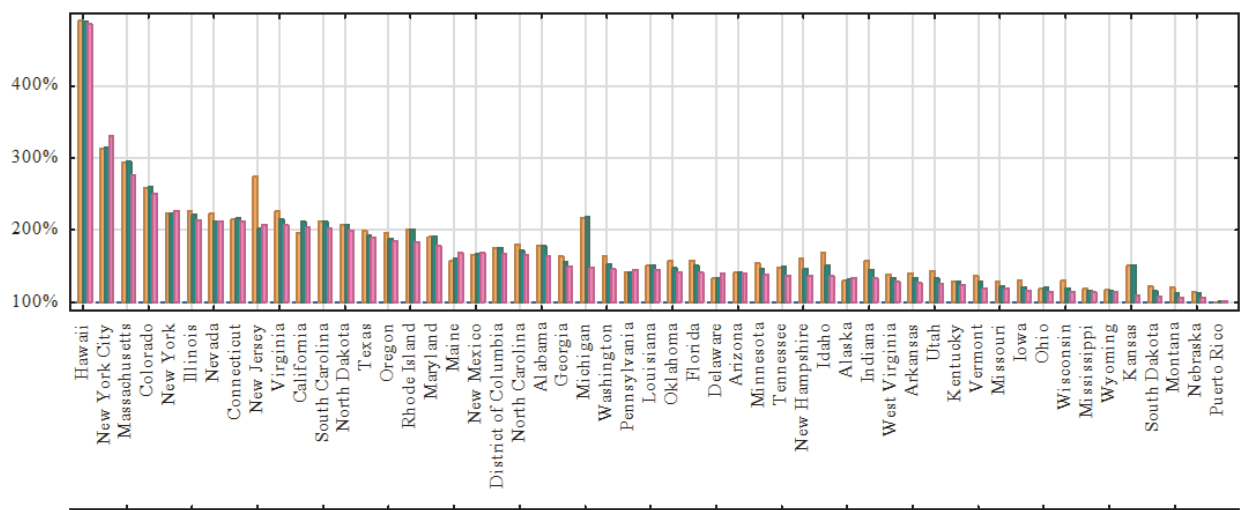

ーNMナロ

January 2020

November 2020

December 2020

January 2021

Fig. 6. Bar chart of dynamics indices based on a fixed number of the unemployed in respective US states (including regions) in four months: January - 2020, November 2020, December 2020 and January 2021 (constant - the number of the unemployed in respective 53 states and regions of the USA in January 2020)

Source: Own study based on data obtained from the website: https://www.bls.gov/news.release/laus. t01.htm, as of March 24, 2021 
The data in Figure 6 shows that from January 2020 to January 2021 an increase in the dynamics indices with a fixed basis was observed which was uneven. It became a premise to perform two rankings for research purposes. The first ranking was made on the basis of January 2021 and is as follows: 1. Hawaii (486.05\%), 2. New York City (330.13\%). 3. Massachusetts (276.39\%), 4. Colorado (250.01\%), 5. New York (226.91\%), 6. Illinois (214\%), 7. Nevada (212.31\%), 8 Connecticut (212.31\%), 9. New Jersey (207.64\%), 10. Virginia (206.64\%), 11. California (203.94\%), 12. Southern California (203.94\%), 13. North Dakota (199.72\%), 14. Texas (189.83\%), 15. Oregon (184.55\%), 16. Rhode Island (183.95\%), 17. Maryland (177.64 \%), 18th Maine (168.75\%), 19.New Mexico (168.15\%), 20. District of Columbia (167.36\%), 21.North California (165.70\%), 22. Alabama ( 164.51\%), 23. Georgia (148.75\%), 24. Michigan (147.55\%), 25. Washington (145.56\%), 26. Pennsylvania (145.38\%), 27. Louisiana ( $145.10 \%), 28$. Oklahoma (142.13\%), 30. Delaware (140.19\%), 31. Arizona (139.44\%), 32. Minnesota (137.87\%), 33. Tennessee (137.87\%), 34. New Hampshire (136.41\%), 35. Idaho (135.99\%), 36. Alaska (133.56\%), 37. Indiana (132.62\%), 38. Virginia West (127.86\%), 39. Arkansas (126.74\%), 40. Utah (125.46\%), 41. Kentucky (124.10\%), 42. Vermont (119.48\%), 43. Missouri (1 18.35\%), 44. Iowa (116.33\%), 45. Ohio (114.69\%), 46. Wisconsin (114.43\%), 47. Mississippi (113.79\%), 48. Wyoming (113.55\%), 49. Kansas (110.12\%), 50. South Dakota (107.44\%), 51. Montana (106.71\%), 52. Nebraska (106.05\%), and 53. Puerto Rico (101.85\%).

The second ranking refers to the median of the considered indices of dynamics with a fixed base in four months: January - 2020, November 2020, December 2020, January 2021 and it looks as follows: 1. Hawaii (487.65\%), 2. New York City (313.49\%), 3. Massachusetts (285.08\%), 4. Colorado (254.53\%), 5. New York (223.61\%), 6. Illinois (218.05\%), 7. Connecticut (214.10\%), 8. Nevada (212.59\%), 9. Virginia (210.70\%), 10. South Carolina (206.83\%), 11. New Jersey (204.70\%), 12. North Dakota (203.49\%), 13. California (200.34\%), 14. Rhode Island (192.26\%), 15. Texas (191.05\%), 16. Oregon (186.18\%), 17. Maryland (184.02\%), 18. Michigan (181.85\%), 19. District of Columbia (171.31\%), 20. Alabama (171.10\%), 21. North Carolina (168.84\%), 22. New Mexico (166.37\%) 23. Maine (159.12\%) 24. Georgia (152.36\%) 25. Washington (149.02\%) 26. Louisiana (147.91\%) 27. Florida (145.73\%), 28. Oklahoma (144.83\%), 29. Idaho (143.78\%), 30. Tennessee (142.71\%), 31. Pennsylvania (141.76\%), 32. Minnesota (141.74\%), 33. New Hampshire (141.61\%), 34. Arizona (140.13\%), 35. Indiana (138.59\%), 36. Delaware (133.44\%), 37. Alaska (130.68\%) 38. West Virginia (130.55\%), 39. Arkansas (130.37\%), 40. Kansas (130.33\%), 41. Utah (129.56\%), 42. Kentucky (126.58\%), 43. Vermont (124.27\%), 44. Missouri (120.29\%), 45. Iowa (118.88\%), 46. Ohio (117\%), 47. Wisconsin (116.73\%), 48. Mississippi (114.95\%), 49. Wyoming (114.32\%), 50. South Dakota (111.30\%), 51. Montana (110.01\%), 52. Nebraska (109.16\%) and 53. Puerto Rico (100.45\%). 
The unemployment rates have been calculated it the study in respective US states and regions in the months: January - 2020, November 2020, December 2020 and January 2021, using the following formula:

$$
S_{B}=\frac{L_{B}}{L_{Z}+L_{B}} \cdot 100 \%,
$$

where: $S_{B}$ - unemployment rate,

$L_{B}$ - the number of the unemployed,

$L_{Z}-$ number of employees.

The results of the obtained values of the unemployment rates in the analyzed data in respective US states in the months: January - 2020, November 2020, December 2020 and January 2021 were ranked, taking their median as a basis from the highest to the lowest value, and summarized in Figure 7.

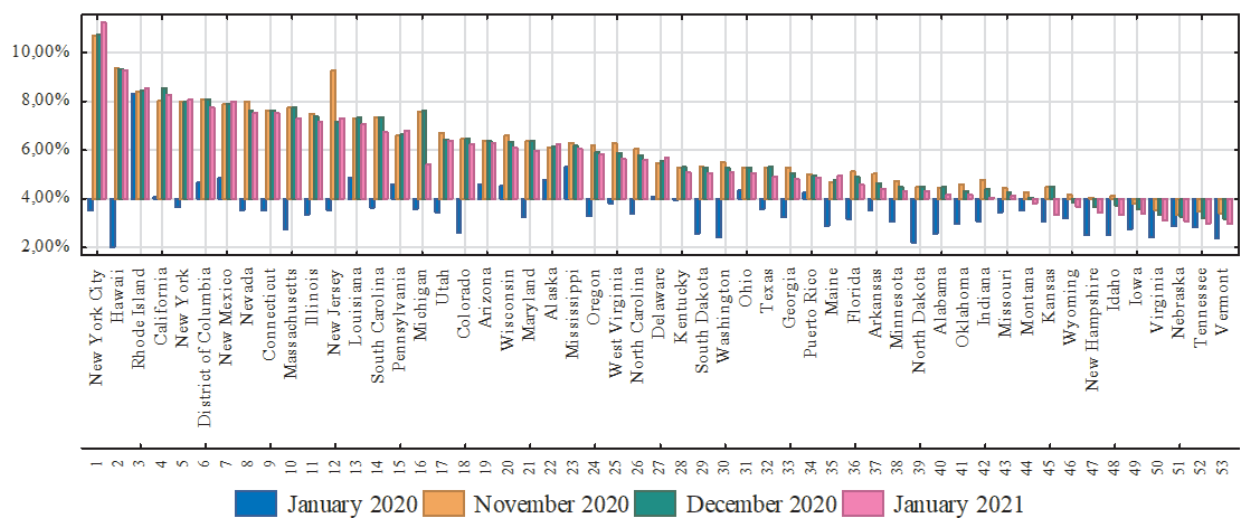

Fig. 7. Bar chart of unemployment rate indices by US states and regions in four months: January 2020, November 2020, December 2020 and January 2021

Source: own study based on data obtained from the website: https://www.bls.gov/news.release/laus. t01.htm, as of March 24, 2021

The research shows that in 23 states and regions of the USA, the unemployment rate from January 2020 to January 2021 exceeded $6 \%$ while in the remaining 30 states and regions of the USA it was lower. The results of the ranking of the unemployment rates (Fig. 7), assuming the median of the four analyzed months, were quantified from the highest to the lowest value: 1. New York City (10.71\%), 2. Hawaii (9.30\%), 3. Rhode Island (8.40\%), 4. California (8.13\%), 5. New York City (7.98\%), 6. District of Columbia (7.91\%), 7. New Mexico (7.89\%), 8. Nevada (7.56\%), 9. Connecticut (7.55\%), 10. Massachusetts (7.50\%), 11. Illinois (7.27\%), 12. New Jersey $(7.24 \%)$, 13. Louisiana (7.18\%), 14. South Carolina (7.04\%), 15. Pennsylvania (6.61\%), 16. Michigan (6.48\%), 17. Utah (6.41\% ), 18. Colorado (6.34\%), 19. Arizona (6.32\%), 20. 
Wisconsin (6.20\%), 21. Maryland (6.17\%), 22. Alaska (6.12\% ), 23. Mississippi (6.10\%), 24. Oregon (5.86\%), 25. West Virginia (5.75\%), 26. North Carolina (5.68\%), 27. Delaware (5, 50\%), 28. Kentucky (5.18\%), 29. South Dakota (5.17\%), 30. Washington (5.17\%), 31. Ohio (5.16\%), 32. Texas (5, 08\%), 33. Georgia (4.93\%), 34. Puerto Rico (4.90\%), 35. Maine (4.72\%), 36. Florida (4.72\%), 37. Arkansas (4.53\%), 38. Minnesota (4.41\%), 39. North Dakota (4.40\%), 40. Alabama (4.30\%), 41. Oklahoma (4.24\% ), 42. Indiana (4.22\%), 43. Missouri (4.18\%), 44. Montana (3.93\%), 45. Kansas (3.91\%), 46. Wyoming (3.76\% ), 47. New Hampshire (3.56\%), 48. Idaho (3.52\%); 49. Iowa (3.49\%), 50. Virginia (3.23\%), 51. Nebraska (3.17\%), 52. Tennessee (3.08\%) and 53. Vermont (3.08\%).

The information presented in Figure 7 shows that the unemployment rate in particular states and regions of the USA is systematically decreasing in most of the analyzed explanatory variables (unemployment rate) of dependent variables (considered month). The exceptions include the New York City region where the unemployment rate increased until January 2021.

\section{Summary and conclusions}

The research shows that the number of employees in six states exceeds 6 million people and in the leaders it fluctuates around 18 million (California). In 30 US states, the number of employees is less than 3 million. The states with the highest number of employees include: 1. California $(18,687,224), 2$. Texas $(14,098,306)$, 3. Florida $(10,056,390), 4$. New York $(9,287,303), 5$. Pennsylvania $(6310,522), 6$. Illinois $(6,155,950), 7$. Ohio $(5,766,458), 8$. Georgia $(5,114,420), 9$. North California $(5,039,346)$. All of the other states employ less than 5 million people.

The decrease in the number of employees in the United States between January 2020 and 2021 was by $4,114,971$ people. The largest drops were recorded in the following states: California (-768,143); Florida (-390 149); Pennsylvania (-236,741) and New York $(-233,924)$.

The indexes of dynamics compiled in the study based on a fixed number of employees in respective US states (Fig. 3) show that between January 2020 and January 2021 in ten US states and regions there was a noticeable upward trend. On the other hand, in the remaining US states, it is typically downward.

During the COVID-19 pandemic, unemployment rates rose in all US states and regions. The highest increases in unemployment were observed in the following US states and regions: California $(1,650,425)$, Texas $(964,877)$, New York $(804,877)$, Florida $(498,423)$, Illinois $(498,423)$ and New York City $(462,252)$.

The highest difference in the number of unemployed people between the same month of January in the period 2020-2021 was recorded in the following US states: California (856,303), Texas $(456,781)$, New York $(453,690)$, New York City $(340,806)$, Florida $(251,960)$. 
From January 2020 to January 2021, an increase in the dynamics indices with a fixed base (Fig. 6) was observed which was uneven. The largest increases were observed in the following US states and regions: Hawaii (486.05\%), New York City (330.13\%), Massachusetts (276.39\%), Colorado (250.01\%), New York (226.91\%), Illinois (214\%), Nevada (212.31\%), Connecticut (212.31\%), New Jersey (207.64\%), Virginia (206.64\%), California (203.94\%), Southern California (203.94\%). In each of the others, it was lower than $200 \%$.

In 23 US states and regions, the unemployment rate from January 2020 to January 2021 exceeded $6 \%$ while in the remaining 30 US states and regions it was lower. The highest values of the unemployment rate were recorded in: New York City $(10.71 \%)$, Hawaii (9.30\%), Rhode Island (8.40\%), California (8.13\%), New York (7.98\%), District of Columbia (7.91\%), New Mexico (7.89\%), Nevada (7.56\%), Connecticut (7.55\%), Massachusetts (7.50\%), Illinois (7.27\%), New Jersey (7.24\%), Louisiana (7.18\%), South Carolina (7.04\%), Pennsylvania (6.61\%), Michigan (6.48\%), Utah (6.41\%), Colorado (6.34\%), Arizona (6.32\%), Wisconsin (6.20\%), Maryland (6.17\%), Alaska (6.12\%), Mississippi (6.10\%). In other states, it was below 6\%. The lowest unemployment rates were recorded in Vermont (3.08\%) and Tennessee (3.08\%).

Even the world's strongest economies are vulnerable to the effects of financial, economic and other crises. The goal of governments is to introduce measures to overcome obstacles and return to the pre-crisis situation as quickly as possible. One of the forms of action are well-thought-out long-term international agreements. However, it requires preparing society to function at the pre-pandemic level by ensuring people's health safety by vaccinating the majority of the population.

\section{BIBLIOGRAPHY}

[1] Begg, D., Vernasca, G., Fischer S., Dornbusch R., 2014. Makroekonomia, Warszawa: Polskie Wydawnictwo Ekonomiczne.

[2] Kingsley, K., Kouam, H., January 2020. COVID-19 and oil prices, SSRN Electronic Journal, DOI:10.2139/ssrn.3555880.

[3] Kozicki, B., Kalwasiński, M., 2021. Multivariate comparative analysis of unemployment rates in the United States and China. COVID-19 versus economic security, International Business Information Management Conference (37th IBIMA), Cordoba, Spain.

[4] Łuniewska, M., TARCzyŃski, W., 2006. Metody wielowymiarowej analizy porównawczej na rynku kapitałowym, Warszawa: PWN.

[5] Matuka, A., September 2020. COVID-19 Outbreak and US Economic Policy Uncertainty: An ARDL Approach, SSRN Electronic Journal, https://www.researchgate.net/publication/344083397

[6] Мiткоw, Sz., Kozicкi, B., 2021. Multidimensional comparative analysis and forecasting of unemployment in the USA for 2021 in the aspect of economic security, International Business Information Management Conference (37th IBIMA), Cordoba, Spain.

[7] Nermend, K., 2017. Metody analizy wielokryterialnej i wielowymiarowej we wspomaganiu decyzji, Warszawa: PWN. 
[8] Nurzyńska, A., 2016. Bezpieczeństwo usług w międzynarodowym transporcie lotniczym przewozów pasażerskich. Katowice: Wydawnictwo Naukowe Sophia.

[9] Owsıak, S., 2015. Finanse, Warszawa: Polskie Wydawnictwo Ekonomiczne.

[10] Satomi, E., AND other, April 2020. Alocação justa de recuros de saúde escassos diante da pandemia de COVID-19 Considerações éticas, Einstein (São Paulo 18(2):1-5, DOI: 10.31744/ einstein_journal/2020AE5775).

[11] Zhu, N., Zhang, D., Wang, W., Li, X., Yang, B., Song, J., et Al., 24 January 2020. A Novel Coronavirus from Patients with Pneumonia in China, 2019, New England Journal of Medicine.

[12] https://businessinsider.com.pl/twoje-pieniadze/praca/bezrobocie-w-kwietniu-2020-r-w-usaspowodowane-koronawirusem/gk157xg.

[13] https://www.ajmc.com/view/a-timeline-of-covid19-developments-in-2020.

[14] https://www.bankier.pl/wiadomosc/Etniczne-bezrobocie-w-USA-Czarni-za-latynosami-bialymii-Azjatami-7318770.html.

[15] https://www.bls.gov/news.release/laus.t01.htm.

[16] https://www.dol.gov/coronavirus/unemployment-insurance.

[17] https://www.naukowiec.org/wzory/ekonomia/stopa-bezrobocia_906.html.

[18] https://www.nejm.org/doi/full/10.1056/NEJMoa2001191.

[19] https://www.theguardian.com/business/2020/mar/26/us-unemployment-rate-coronavirusbusiness.

[20] https://historia.org.pl/2020/04/03/wielki-kryzys-gospodarczy-1929-1933-najwiekszy-kryzys-whistorii-kapitalizmu/.

[21] https://www.pewresearch.org/fact-tank/2020/06/11/unemployment-rose-higher-in-three-monthsof-covid-19-than-it-did-in-two-years-of-the-great-recession/.

[22] https://eu.usatoday.com/story/money/2020/08/08/cities-with-the-worst-unemployment-sincethe-pandemic-started/42187029/.

[23] https://www.worldometers.info/.

[24] https://www.weforum.org/agenda/2020/12/covid19-pandemic-usa-employment-inequality/.

[25] https://www.theguardian.com/business/2020/dec/31/us-unemployment-december-coronavirus.

[26] https://www.pewresearch.org/fact-tank/2021/02/10/unemployed-americans-are-feeling-theemotional-strain-of-job-loss-most-have-considered-changing-occupations/. 
